DOI: https://doi.org/10.32839/2304-5809/2020-78.1-7

УДК 37.013

Івасюта О.Б.

Львівський національний університет імені Івана Франка

\title{
ЛІнГВОКУЛЬТУРНИЙ ВИМІР КИТАЙСьКОГО СИМВОЛУ
}

\begin{abstract}
Анотація. У статті проаналізовано лексико-семантичні та комунікативні аспекти китайських символічних одиниць, а також розглядаються їхні екстралінгвістичні (прагматичні, соціокультурні, історичні та психологічні) основи (Ч. Вільямс, В. Ебергард, Г. Морган). Візуальність китайської мови та значна кількість омонімів слугують джерелом символізму (риба як символ багатства і надлишку). Коріння китайської символіки соціокультурне, оскільки історично суспільству була притаманна скритність та стриманість. Використання специфічних соціальних символів є традиційним, створюе глибинний рівень спілкування, потенційно багатший на нюанси та відтінки значень. У таксономії Китаю простежуеться чітка іерархія: людина, її артефакти та діяльність, природні явища, фрлора, фрауна. 3 фрілософрських джерел беруть початок найчисленніші символи даосизму (dao).
\end{abstract}

Ключові слова: символіка, китайський символ, лінгвокультурний, характеристика, етнокультурний, транскультурний.

Ivasyuta Olena

Ivan Franko National University of Lviv

\section{LINGUOCULTURAL DIMENSION OF THE CHINESE SYMBOL}

Summary. The article deals with the linguocultural specificity of Chinese symbolism based on the anthropological approach. Chinese symbolism is unique in view of its being a part of the language and culture simultaneously. An attempt has been made in the article to investigate the contextual and communicative potential of Chinese symbols. Symbols under investigation are of two basic types: archetypal and ethnocultural. The analysis, based on the works of such scholars as: W. Eberhard, H.T. Morgan, U. Becker, M. Bruce-Mitford, J. Chevalier, J.E. Cirlot, proves that a direct correlation between symbols and concepts in Chinese culture should be regarded as that of paramount importance when represented to the Western reader through works of fiction. Thus, the article also considers the difficulties of transcultural perception of Chinese symbols. The linguocultural analysis of Chinese symbolism has revealed its origin, characteristics, and modifications. Its foundation is sociocultural; the human being is the central figure of Chinese symbolic taxonomy. Animals, plants, even the sky and earth are subjected to the man. Flora, fauna and philosophy are well represented in Chinese symbolism. Symbols are rooted in both religious and secular traditions, in Chinese philosophy and nature; their sources are myth and history alike. Visual nature of the Chinese language and a large number of homonyms serve as another important source of symbolism (fish is wealth and prosperity). Symbols are interconnected by means of associative-and-semantic ties. The concept and symbol of Dao appears to be one of the most powerful, it generates senses on multiple levels and the philosophical and religious tradition of Daoism (Taoism) has originated from it. According to F. Lessing, the "symbolic language" of the Chinese is the second form of language that permeates their existence and communication, creating a second deeper level of communication, potentially stronger than ordinary language, richer in nuances and shades of meaning.

Keywords: symbolism, Chinese symbol, linguocultural characteristics, ethnocultural, transcultural.

$\Pi$ остановка проблеми. Процес глобалізації торкнувся багатьох сорер гуманітарного та культурного життя людини і в цих умовах гостро відчувається потреба взаєморозуміння. На перетині мов та культур постають нові цінності, зазнають змін етнокультурні особливості народів. На цьому тлі важливим є дослідження символіки як глибинного лінгвокультурного фpeномену. Антропоцентрична природа символів робить їх привабливими в сучасних комунікативно-орієнтованих мовознавчих студіях.

Актуальність статті визначається, поперше, ключовим місцем символу в лінгвістичній, лінгвокультурній та літературній системах; по-друге, зумовлена недостатнім вивченням символів як мовних одиниць, що реалізують специфріку світобачення окремого етносу.

Матеріалом статті слугувала вибірка зі словників китайської символіки.

Мета статті. Головною метою роботи $є$ аналіз лінгвокультурних аспектів та екстралінгвістичних (прагматичних, соціокультурних, історичних та психологічних) основ китайських символів.
Виклад основного матеріалу. Китайський символізм грунтуеться на мовах Китаю, соціумі, фрілософріï і на анімізмі. Китайські мовні знаки $є$ малюнками, їхня мова $є$ візуальною, тому для китайців мовні знаки є символами. Малюнок і письмо в китайській мові перегукуються і перетинаються. Значна кількість омонімів також $€$ джерелом символізму. Коріння китайської символіки соціокультурне, оскільки історично суспільству була притаманна потаємність і стриманість. Із соціокультурних причин ще одним джерелом символіки став пейзаж. Отже, в традиції Китаю панувало використання специфрічних соціальних символів.

Центральним об'єктом для всіеї таксономії Китаю є людина в їі тілесному існуванні, соціальному середовиші, 3 їі артедрактами та діяльністю. Людині підкоряються тварини, рослини, небо i земля. Символи орлори i фоауни представлені в китайській традищії різноманітно, фрлора є більш важливою, ніж фауна, важлива також символіка природних явищ - хмари, дощ, роса, грім. Значна група символів пов'язана із запахом чи смаком. 
Iз фрілософрських джерел найбільш плідним у символізмі виявився даосизм, дао - шлях, оскільки лише там, де $є$ шлях панує порядок. Релігійна символіка не властива Китаю.

Символи китайці вважають тонким і багатогранним способом вираження. У повсякденному житті вони використовують мову символів як другу форму мови, що пронизуе їхне буття та спілкування, створює глибинний рівень спілкування, потенційно багатший на нюанси та відтінки значень.

Визначаючи специфіку китайських символів, ми спиралися на дослідження відомих сінологів XX століття, а саме В. Ебергарда, Ч. Вільямса, Г. Моргана [9; 11; 13]. Звертаючись до першооснов китайського символізму, Ч. Вільямс шукає підѓрунтя, яке поклало початок існуванню яскравих форм у китайській ментальності, і знаходить його в еволюції азійської думки [13]. Відомо, що впродовж тисячоліть жителям Азії був притаманний анімізм, тобто одухотворення живих та неживих природних об'єктів. Часто ці духи населяли скелі, дерева та тварин і вважалися душами померлих предків, які дбали про своїх нащадків. Деякі духи були казковими істотами, але, на переконання китайців, усі ці надприродні створіння впливали на людське життя.

Релігії трансформували давні анімістичні вірування: вчення Лао Цзи, Конфруція, а згодом запозичений в індійців буддизм дали Китаю його вічні ідеали життя та смерті. Китайський символізм, таким чином, Ірунтуеться і на фрілософрї, і на релігії, і на видозміненому примітивному анімізмі [11, с. 21].

Уявлення європейців про Китай та китайців мінялися впродовж століть. У часи античності Китай був таємничою країною, про яку було мало відомостей. У середні віки до кінця XVIII століття було відомо лише, що Китай - величезна країна зі стабільною владою і вишуканими традиціями та манерами, і цим европейці захоплювалися. У Китаї навіть селяни поводяться з гідністю і стриманістю, яка в Європі притаманна лише знаті [9].

У подальшому військова слабкість Китаю перетворила його на жертву колоніальних сил. На початку XX століття окремі европейці почали усвідомлювати, що для розуміння Китаю необхідним є знання китайської мови, культури та літератури. Саме Р. Вільгельм, котрий був пастором та місіонером в німецькій колонї в Кіачові, зміг завдяки своїм перекладам та оригінальним творам змінити німецьке бачення Китаю лише за два десятиліття. Він був переконаний, що люди на Заході можуть багато запозичити з орієнтального способу життя та способу мислення.

Минуло 100 років, але питання про те, чи мислення китайців відрізняеться від способу мислення людини західної цивілізації, все ще відкрите. Як доказ на користь цього твердження деякі вчені наводять саме китайську мову. У китайській мові не існує відмін та дієвідмін. В основі, китайське слово складається з одніеї незмінної фонеми: існуе приблизно 400 таких базових фонем. Дві чи більше фонем можна поєднувати і в такий спосіб формувати нові слова. Північнокитайська мова має чотири тони (тобто кожна базова фонема може вимовлятися чотирма різними інтонаціями 3 відповідною зміною значен- ня), і це дає чотирикратне розширення існуючих фонем. I навіть при цьому кількість омонімів залишається дуже високою.

З іншого боку, китайській мові притаманна певна граматична скупість у порівнянні із мовами індоєвропейської сім”і, у яких розвинутий складний морфологічний апарат. Наприклад, біля множин-

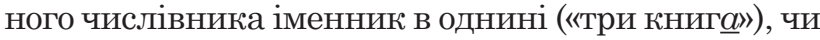
не вказується граматичний час дієслова, оскільки час дії зрозумілий з контексту («Я $\underline{\epsilon}$ у театрі вчора»). Не виражається також граматичний рід в іменниках $[9$, с. 8]. Така граматична особливість має певні недоліки, оскільки китайську фразу поза контекстом зазвичай важко зрозуміти.

Незначна частина китайських знаків - близько $200-\epsilon$ безпосередніми відображеннями природних об'єктів; усі інші є складними знаками. Усі китайські знаки є по своїй суті картинами, тому вони привертають увагу візуально, тоді як індоєвропейським мовам притаманне аудіосприйняття. Тому для китайців їхні знаки є символами, а не лише способом записування звуків. Донедавна в китайській мові не було окремого слова «символ», для цього використовувалось слово xiang, що означає "малюнок". За К.Г. Юнгом, слово чи картина (образ) є символічними якщо вони містять у собі більше, ніж можна побачити на поверхні [3]. Е. Преторіус стверджуе, що в китайській мові «картина і письмо настільки одне з одним перегукуються у змісті та фрормі, що вони часто повністю взаємопроникні» [9, с. 9].

Лінгвокультурна специфріка китайської мови полягає у притаманності їй великої кількості омонімів, на основі яких утворюються каламбури. Як приклад візьмемо вираз «уоu уu», який може означати "він має багато/безліч», «у нього у надлишку» (напр. багатств) або ж «ось риба». Тож картина, на якій є риба, - каламбур, і реципієнт розуміє, що йому бажають «багатства і надлишку у всьому». У більшості мов поняття «безліч, надлишок» природно виводиться з уявлення «риба відкладає безліч ікринок»; а в китайській мові достатньо лише фонетичної еквівалентності. Такі каламбури сприймаються на слух, хоча багато з них апелюють візуально, оскільки якщо каламбури базуються не на мандаринській (висока китайська, мова офріціозу), а на якомусь 3 діалектів, то цю вимову зазвичай важко сприймати. Тому китайці переважно створюють каламбури, що базуються на зоровому сприйнятті [9, с. 10].

В. Ебергард, відомий дослідник китайської культури та символіки, підкреслюе, що китайським мовцям історично була притаманна таємничість, небажання відкрито говорити про те, що мали на увазі, і ця риса, маючи соціокультурне коріння, у мові відобразилася у складній символічно-метафоричній системі [9]. Свропейські мандрівники й місіонери, які відвідували Китай у 16-18 століттях, описували китайців як людей «старих», тобто, спокійних і суворих у своїй мудрості, але «позбавлених» життя.

Те, що европейські мандрівники сприймали як «позбавленість» життя, було крайньою стриманістю та скритністю, оскільки китайці завжди були змушені зважати, як інші відреагують на будьяку озвучену думку. Так сорормувалося суспільство, яке використовувало символічні форми і способи вираження. Це підкріплювалося ритуалами, 
щоб максимально інтегрувати людину у громаду з її порядком та моральністю [4; 9]. Цікаво відзначити, що до недавнього часу в китайській мові не було слів на позначення «свободи, волі» в політичному чи фрілософрському сенсі. Слово «цзи ю», що досі використовуеться для позначення «свободи», означає "бути на самоті», "бути залишеним наодинці», і воно має негативне забарвлення [11].

Якщо спробувати класифрікувати об'екти, які китайці використовують в якості символів у різних групах, результати $е$ цікавими. Найбільш важливим об'єктом, центральним для всієї таксономії, виявляеться людина: людина в її тілесному існуванні, і в ії сощіальному середовищі, а також ïi артефакти, те, що вона робить. Це відповідає основним принципам китайського світогляду, людина - основна істота в цьому світі. Людині підкоряються тварини, рослини, навіть небо і земля [1]

У царстві живої природи, тваринні символи є більш важливими, ніж рослинні. Проте, символи домашніх тварин не фігурують так часто, як диких. Тварини розглядалися амбівалентно - багато 3 них загрожують людині фрізично і мають властивості, якими людина захоплюеться. Що ж до аналізу сновидінь у китайській культурі, символи бика, свині чи домашньої птиці зустрічаються рідко [11]. Що стосується рослин, то майже всі дерева і чагарники мають значення у повсякденному житті, як важливі джерела фрруктів, сировини для парфумерії або ж будівельного матеріалу. Тому символіка фрлори займає значне місце в системі китайських символів. Це стосуеться природних явищ, таких як хмари, дощ, роса, грім, які справляли глибоке враження на людину [11].

Важливий концепт dao - «принцип», «причина» - має багато рівнів сенсу, і саме від одного 3 них розвинувся і поширився даосизм. Це надзвичайно вагоме змістовне поняття у китайській культурі бере свій початок від спостереження природи. Після проливних дощів у глинистих і лісистих районах Північного Китаю утворювалися болота, через які неможливо було пройти; лише тоді і там, де було прокладено шлях (дао), панував «порядок на землі» [12].

Більшість із китайських символів пов'язані з предметами та явищами, які можна спостерігати візуально, i їх можна позначити як формальні символи. Часто, однак, китайські слова позначають поняття, які символізують фонетично еквівалентні речі наприклад, $f u=$ удача, i $f u=$ кажан; таким чином, кажан символізуе удачу. У такому випадку ми можемо говорити про фонетичні або аудіо символи [9, с. 13].

Інша група символів пов'язана із запахом чи смаком. Як стверджують вчені, лише нещодав- но стало очевидним, наскільки важливим для китайців є дотик [9, с. 10]. Цю останню групу символів можна назвати якісними символами. Певні властивості приписують об'єктам, особливо, тваринам і птахам (наприклад, орел, як вважають, зберігає свою силу до глибокої старості) [11]. Більшість китайських символів пов'язані 3 цими основними темами, оскільки вони мали значення в їхньому повсякденному житті. Вони відображали глибинні бажання - прожити довге і здорове життя, досягти високого громадянського і соціального становища і мати дітей (синів).

У традищійному китайському суспільстві були вагомі причини бажати народження саме синів. Після смерті батька, сини піклувалися про сім'ю, вони дбали про те, щоб покійний батько отримав усі необхідні знаки уваги, позаяк він перетвориться на одного з «голодних духів». Китайський чоловік в традиційному суспільстві не міг собі уявити нічого жахливішого, ніж померти, не залишивши сина чи синів. Це одна з причин, чому було дозволено багатоженство (до 1928); хоча ця практика ніколи не була поширена, і лише заможні могли дозволити собі утримувати декілька дружин. Для бідних виходом було взяти на виховання хлопчика з родини, племінника [9, с. 13].

Для китайської культури, на відміну від західної цивілізації, не властива велика кількість релігійної та мистецької символіки. Їхня символіка переважно соціальна, наприклад, якщо європейщі дарують другові чи родичеві квіти, то китайці несуть вазу, декоративний таріль або вишитий гаманець, який буде прикрашений символами [4; 12$]$.

Символи висловлюють те, що можна передати і словами, але в таких ситуаціях китайці вважають, що слова надто примітивні, символ набагато тонший. Лише якщо оглянути i вивчити подарунок можна відшукати два або три символічні знаки, що вкажуть, які саме «хороші побажання» передаються. Те ж саме стосуеться поведінки в суспільстві. Використання символів у повсякденному житті може створювати певну напругу, бо співрозмовник може бути достатньо проникливим, щоб зрозуміти сенс символів, або ж їхне розуміння буде лише частковим [9].

Висновки і пропозиції. Отже, можемо зробити висновок, що лінгвокультурний вимір китайських символів полягає у значній апроксімації мови та культури. Символічне багатство китайської лінгвокультури випливає із лінгвістичних особливостей, а саме розвиненої омонімії, на основі якої розвинувся символічний рівень комунікації. Додатковим фрактором символічності мови є граматична скупість та специфріка китайського правопису.

\section{Список літератури:}

1. Ледже Дж. Конфуций. Сто великих людей мира: Зороастр. Будда. Конфуций. Маголет. Київ : МП «Муза», 1991. С. $71-116$.

2. Лотман Ю.М. Символ в системе культуры. Ученье записки Тартуского гос. ун-та, 1997. 145 с.

3. Юнг К.Г. Человек и его символы. Санкт-Петербург : Б.С.К., 1996. 651 с.

4. Энциклопедия символов, знаков, эмблем / В. Андреева, В. Куклев, А. Ровнер. Москва : Локид-миф, 2000.576 с.

5. Becker U. The Continuum Encyclopedia of Symbols / Udo Becker. New York; London: Continuum, 2000. 345 p.

6. Bruce-Mitford M. Signs \& Symbols: An Illustrated Guide to Their Origins and Meanings / M. Bruce-Mitford. London : Dorling Kindersley Ltd, 2008. 352 p.

7. Chevalier J. The Penguin Dictionary of Symbols / J. Chevalier, A. Cheerbrant. London : Penguin Books Ltd, 1996.1174 p.

8. Cirlot J.E. A Dictionary of Symbols / J.E. Cirlot. London : Routledge \& Kegan Paul Ltd, 2001. 528 p.

9. Eberhard W. A dictionary of Chinese symbols / W. Eberhard. London : Routledge \& Kegan Paul Ltd, 1986. 332 p. 
10. Labov W. The boundaries of words and their meanings / W. Labov // New ways of analysing variation in English / Ed. by J. Fishman. Washington: Georgetown Un. Press. 1973. P. 340-373.

11. Morgan H.T. Chinese Symbols and superstitions / H.T. Morgan. South Pasadena, California, 1942. 192 p.

12. The World Book Encyclopedia (International) USA in 22 v. / World Book, Inc. 1994. V. 3; V. 12; V. 18 ; V. 19.

13. Williams C.A.S. Outlines of Chinese Symbolism and Art Motives / C.A.S. Williams. New York : Tuttle Publishing, 2006. 384 p.

\section{References:}

1. Ledzhe J. (1991). Konfucii [Conficius]. Sto velikikh liudei mira: Zoroastr. Budda. Konfucii. Magomet. Kyiv: MP «Muza», pp. 71-116.

2. Lotman Yu.M. (1997). Simvol v sisteme kultury. [Symbol in the system of culture]. Uchyonyie zapiski Tartusskoho universiteta. Tartu, $145 \mathrm{p}$.

3. Yung K.G. (1996). Chelovek i ego simvoly [A man and his symbols]. SPt.: B.S.K., 651 p.

4. Encyklopedia simvolov, znakov, emblem [Encyclopedia of symbols, signs, emblems]. V. Andreeva, V. Kuklev, A. Rovner. Moscow: Lokid-Mif, 2000. 576 p.

5. Becker U. The Continuum Encyclopedia of Symbols / Udo Becker. New York; London: Continuum, 2000. 345 p.

6. Bruce-Mitford M. Signs \& Symbols: An Illustrated Guide to Their Origins and Meanings / M. Bruce-Mitford. London: Dorling Kindersley Ltd, 2008. 352 p.

7. Chevalier J. The Penguin Dictionary of Symbols / J. Chevalier, A. Cheerbrant. London: Penguin Books Ltd, 1996.1174 p.

8. Cirlot J. E. A Dictionary of Symbols / J.E. Cirlot. London: Routledge \& Kegan Paul Ltd, 2001. 528 p.

9. Eberhard W. A dictionary of Chinese symbols / W. Eberhard. London: Routledge \& Kegan Paul Ltd, 1986. 332 p.

10. Labov W. The boundaries of words and their meanings / W. Labov // New ways of analysing variation in English / Ed. by J. Fishman. Washington: Georgetown Un. Press. 1973. P. 340-373.

11. Morgan H.T. Chinese Symbols and superstitions / H.T. Morgan. South Pasadena, California, 1942.192 p.

12. The World Book Encyclopedia (International) USA in 22 v. / World Book, Inc. 1994. V. 3; V. 12; V. 18 ; V. 19.

13. Williams C.A.S. Outlines of Chinese Symbolism and Art Motives / C.A.S. Williams. New York: Tuttle Publishing, 2006. 384 p. 